\title{
TEACHERS' AWARENESS OF NIGERIA'S EDUCATIONAL POLICY ON ICT AND ITS EFFECT ON THE USE OF ICTS IN OYO STATE SECONDARY SCHOOLS
}

\author{
Olusegun Fatai Adebowale \\ Obafemi Awolowo University, Nigeria \\ Dare Naomi Olufunke \\ Federal Government Girls College, Ipetumodu, Nigeria
}

\begin{abstract}
This study is designed to examine the level of awareness of primary and secondary school teachers invited for a capacity building workshop on ICT of Nigeria's educational policy on ICT as well as its possible influence on the use of ICT for classroom teaching and learning. Two hundred volunteers (out of the 250 participants invited from all the Local Government Areas of the state) at an ICT training workshop organized for Oyo state (Nigeria) teachers participated in this study. Data was collected using a self-constructed and validated questionnaire titled "Teachers awareness of Nigeria's educational policy on ICT" and the data were analyzed using simple percentage, t-test and ANOVA. The study found that only a small percentage of the respondents possess a high level of awareness of the country's educational policy on ICT, in fact, a considerable proportion of the respondents (35.1\%) of the respondents were either completely ignorant of the policy or possess poor levels of its awareness. previous training which some of these respondents attended had no significant influence on their awareness of the country's educational policy on ICT. The study also presented some implications of this to ICTs use for teaching and learning purposes in the schools.
\end{abstract}

Key words: awareness, educational policy, ICT, schools, students, teachers.

\section{Introduction}

The Nigerian Federal Government approved a national IT policy in 2001 with the establishment of the National Information Technology Development Agency (NITDA), charged with the responsibility of kick-starting, coordinating and implementing the provisions of the policy (Ajayi, 2003). It also set up the Nigerian National ICT for Development (ICT4D) Strategic Action Plan committee to develop a new ICT policy for development as the ICT action plan / roadmap for the nation. However, the objectives of the policy and strategies designed to achieve them are essentially political and mildly technical, as education was mentioned just in passing (NITDA, n.d.).

Although, Yususf (2007) stated that ICT policy initiatives since 1988 have been targeted at ensuring the integration of Information and Communication Technology (ICT) in the Nigerian school system, Agyeman (2007) posited that the Federal Republic of Nigeria has no specific policy for ICT in education and Achimugu, Oluwagbemi and Oluwaranti (2010) confirmed that although as the mission, general objectives, and strategies of the national IT policy recognized the importance of ICT in education, the document has no sectored (vertical) application to education. Even, the integration of Information and Communication Technologies (ICTs) in distance education programs in Africa has not been encouraging. The authors acknowledged the fact that the policy has no specific special application to education and that while there are sectored applications for health, agriculture, art, culture, tourism; and governance, education is subsumed under human resource development. 
Also, Yusuf (2007) noted that although computer entered into the Nigeria's education system in the late 70's and early 80's, no concrete policy was evolved for its entry into the nation's education system until the evolvement of the National Policy on Computer Education in 1988 (Federal Republic of Nigeria, FRN, 1988). This document contained information on the application of computer at various levels of the country's education, and with issues related to basic objectives, hardware and software requirements. The document also comments on teacher training, specifically, for the secondary school level.

In recognition of the prominent role of ICTs in the modern world, the Federal Government of Nigeria in the National Policy on Education (Federal Republic of Nigeria, 2004), further stated that government would provide basic infrastructure and training at the primary school, at the junior secondary school, computer education would be a pre-vocational elective, and a vocational elective at the senior secondary school. Adomi and Kpagban (2010) noted that 2004 was not the first Nigerian government attempt to introduce computer education in schools as, in 1988, the Nigerian government enacted a policy on computer education to establish pilot schools and diffuse computer education innovation first to all secondary schools, and then to primary schools. Unfortunately, the project did not really take off beyond the distribution and installation of personal computers (Okebukola, 1997; cited by Adomi and Kpagban, 2010). This author concluded that computer is not part of classroom technology in more than 90 percent of Nigerian public schools.

Specifically, Okafor and Umoinyang (2008) recalled that the National Computer Education Curriculum (NCEC) was developed for primary schools in 2002 by the Nigerian Educational Research and Development Council (NERDC), representing the first deliberate attempt to provide guidance to teachers on what should constitute basic computer literacy concepts and, skills that could be acquired at the Primary School Level. They reported that 97.9 percent of primary school teachers in Ekwusigo LGEA are computer illiterates. They have not acquired basic computer skills for teaching some concepts outlined in the National Computer Education Curriculum for Primary Schools and consequently, almost all the sampled teachers request for in-service training. They also reported that many primary schools and teachers do not have computers to practice on their own,

However, Owhotu (2006) in Adeosun (2010) claims that, Nigeria has been in the lead within her sub-region in the integration of ICT tools with a number of initiatives; through collaborations with the government, by development partners, NGOs (international and local) and private corporations. Adeosun (2010) further highlighted some initiatives implemented to integrate ICT into Nigerian educational concerns as follows:

a. SchoolNet Nigeria: This is an affiliate of SchoolNet Africa, launched in Nigeria in September 2001 and funded by Education Trust Fund. SchoolNet is engaged in the effective and sustainable deployment and use of Information and Communication Technologies (ICTs) to enhance teaching and learning in the primary and secondary education sector.

b. Education Trust Fund (ETF): This fund was developed from 2\% of companies' profit tax which is distributed by the Education Trust Fund for educational purposes. Besides working with SchoolNet Nigeria, ETF also works on the Education Resource Center project which aims to create science labs, ICT laboratories, libraries and multi-purpose halls in schools and institutions of higher learning.

c. Computers-in-Schools project: The project was kick-started in 2002 with the major objective to develop computer and technological literacy through the introduction of computers in secondary schools. A programme similar to this was reported to have 
been established by the Lagos state government in 2005 (Adebowale, Adediwura and Bada, 2009; Adebowale, Adewale and Oyeniran, 2010)

d. One-laptop- per-child (OLPC): This project was launched in Nigeria in September 2006 (Adeosun, 2010) by the one laptop- per-child (OLPC) initiative in collaboration with the Nigerian government which has resulted in the provision of 100-dollar laptop for the e-secondary school project in Nigeria. Nigerian software developers are concentrating on integrating local curriculum content into the project, covering every subject in the school system from JSS 1-JSS 3 and then SSS 1-SSS 3. However, its effort may have been hampered by a law suit instituted by Lagos Analysis Corporation, also called Lancor a Lagos, US-based Nigerians owned company against OLPC in the end of 2007 for \$20 million, claiming that the computer's keyboard design was stolen from a Lancor patented device. In January 2008, the Nigerian Federal Court rejected OLPC motion to dismiss Lancor's lawsuit and extended its injunction against OLPC distributing its XO Laptops in Nigeria. OLPC appealed the Court's decision but the Appeal is still pending in the Nigerian Federal Court of Appeals (Wikipedia, 2011).

e. Other initiatives that deserve mentioning include the National Infrastructure framework for Open and Distance Learning, Virtual Library project, Microsoft IT academies, etc.

Adeosun (2010) commented that ICT efforts in Nigeria are majorly driven by private initiatives, are often piloted, short term, donor-funded projects which give no room for continuity and sustainability. According to her, they often show pockets of efforts with no coordination, resulting in poor distribution of resources, duplication of efforts and lack of meaningful results. She argued that, although, there are often data supplied to support the impact of these programs, the percentage of beneficiaries is small compared to the number of school age children that require such opportunities.

According to Agyeman (2007), electrical energy problem motivated the Nigerian government to embrace the US\$100 XO laptop computer project for Nigeria's 24 million public primary school children. He also reported that the government has ordered one million of these laptops, which can be cranked and do not need external power supply, for the primary school children. The laptop has in-built wireless networking, uses a $512 \mathrm{MB}$ flash memory without a hard disk, and has two USB ports to which more memory or devices could be attached. It has a new user interface known as Sugar, and comes with a Web browser and a Web processor, but he concluded that the laptops are yet to appear in the country.

Agbatogun (2010) asserted that across the globe, teachers' roles and power of influence cannot be undermined in the successful implementation and sustainability of any innovation or national reform (also Albirini, 2004; Baylor \& Ritche, 2002 in Agbatogun 2010). He further argued that, the level of success in ICT integration in schools cannot be dependent on quality or sophistication of the technology, but rather on the teachers' readiness and positive disposition (Deniz, 2007).

Even in Nigerian universities, Ololube, Ubogu and Ossai (2006) found that most lecturers $(85.9 \%)$ do not know about the IT policy in Nigeria, hence cannot focus any of their teaching towards the goal of the policy as the teaching curriculum does not instruct so. Research to ascertain if such knowledge exists at the secondary school level is either non-existent or very scarce. Consequently, this study is focused at ascertaining if secondary school teachers are aware of some of the provision of the available policy on ICT as it relates to education, using Oyo state as the research field. It also explored the possible influence of the teachers' awareness of the policy on classroom use of ICTs. 
Given the important roles teachers play in the implementation of most educational policies and in particular, that of integration of ICT into teaching and learning the study is designed to investigate the level of teachers' awareness concerning Nigeria's educational policy on ICT and its influence on the usage of ICT in teaching and learning in Oyo state schools. Consequently, three research questions and two hypotheses were drawn to direct the study. The research questions include:

1. What is the level of the teachers' awareness of Nigeria's educational policy on ICT.

2. Does teachers' attendance at previous ICT workshops/ trainings have any difference on their awareness of the policy?

3. What is the teachers' response to the ICT use parameters considered in this study? and the hypotheses include

1. There is no significant influence of the respondents' perceived level of ICT skills on their awareness of the country's educational policy on ICT

2. Teachers awareness of the country's educational policy on ICT will not significantly influence ICT use in Oyo state schools

\section{Methodology of Research}

This was an exploratory study using a descriptive survey design. Two hundred volunteers at an ICT training workshop organized for Oyo state (Nigeria) teachers participated in this study. They were 250 teachers in all, invited from all the 30 Local Government Areas of Oyo state. Out of the 200 questionnaires distributed only those of 188 respondents were usable and hence used. Others were either not returned, defaced or were returned blank. The characteristics of the participants are presented in Table 1.

Table 1. Characteristic features of the study participants

\begin{tabular}{|c|c|c|c|}
\hline Characteristics & Level & $\begin{array}{l}\text { Frequ- } \\
\text { ency }\end{array}$ & Percent \\
\hline \multirow[t]{4}{*}{ Sex } & Male & 100 & 53.2 \\
\hline & Female & 80 & 42.6 \\
\hline & No response & 8 & 4.3 \\
\hline & Total & 188 & 100.0 \\
\hline \multirow[t]{7}{*}{ Age } & less than 20yrs & 2 & 1.1 \\
\hline & 20-30yrs & 14 & 7.4 \\
\hline & $31-40 y r s$ & 64 & 34.0 \\
\hline & $41-50 \mathrm{yrs}$ & 43 & 22.9 \\
\hline & Above 50yrs & 58 & 30.9 \\
\hline & No response & 7 & 3.7 \\
\hline & Total & 188 & 100.0 \\
\hline \multirow{7}{*}{$\begin{array}{l}\text { Educational Quali- } \\
\text { fication }\end{array}$} & $\mathrm{NCE}$ & 62 & 33.0 \\
\hline & HND & 6 & 3.2 \\
\hline & B.A/B.Sc./B.Tech & 35 & 18.6 \\
\hline & B.Ed/B.A.Ed/B.Sc.Ed. & 70 & 37.2 \\
\hline & M.A./M.A.Ed./m.Sc.Ed & 9 & 4.8 \\
\hline & No response & 6 & 3.2 \\
\hline & Total & 188 & 100.0 \\
\hline \multirow{2}{*}{$\begin{array}{l}\text { Teaching experien- } \\
\text { ce }\end{array}$} & Less than 5yrs & 17 & 9.0 \\
\hline & 5-10yrs & 54 & 28.7 \\
\hline
\end{tabular}




\begin{tabular}{|l|l|c|c|}
\hline \multirow{5}{*}{ School taught } & $11-20 y r s$ & 39 & 20.7 \\
\cline { 2 - 4 } & More than 20yrs & 69 & 36.7 \\
\cline { 2 - 4 } & No response & 9 & 4.8 \\
\cline { 2 - 4 } & Total & 188 & 100.0 \\
\cline { 2 - 4 } & Primary & 97 & 51.6 \\
\cline { 2 - 4 } & Junior secondary & 76 & 40.4 \\
\cline { 2 - 4 } & Senior secondary & 11 & 5.9 \\
\cline { 2 - 4 } & No response & 4 & 2.1 \\
\cline { 2 - 4 } & Total & 188 & 100.0 \\
\hline
\end{tabular}

The instrument used in the study is a self-constructed questionnaire titled "Teachers awareness of Nigeria's educational policy on ICT'. It consists of two sections - A and B Section A collected information on participant demographics on one hand and their views on the use of ICT on the other while section B are made of items about different policy provisions of the Nigeria's educational policy on ICT to which respondents are expected to indicate their level of awareness. The instruments have been earlier pretested on 30 teachers made up of an admixture of primary and secondary school teacher in a separate workshop centre. By so doing the instrument was validated and reliability (Alpha) value of 0.867 was obtained while the testretest reliability yielded 0.812 . The questionnaire were administered to the participant early on the third day of the workshop such that they would have been conversant with what is meant by ICT and then be able to properly attend to all the items over a period of 45 minutes. Respondents who needed more time were allowed to submit at the end of the day's activity about $5 \mathrm{hrs}$ later. The data collected were analyzed using simple percentages, t-test and ANOVA.

\section{Results of Research}

Research Question 1: What is the level of the teachers' awareness of Nigeria's educational policy on ICT.

To answer this research question, teachers responses to the section $\mathrm{b}$ of the questionnaire was scored in such a way that when they respond "Highly aware" to an item they are scored 2, but if the response is "Fairly aware", they are scored 1 and 0 if they tick "Not aware". The resulting scores for each respondent is then cumulated and used to build a measure of awareness. The resulting cumulative scores are now categorized in such a way that a cumulative score of 10 or less is used to depict "Complete ignorant", when the respondent scores 11 to 20 , s/he is said to possess "poor level of awareness", 21 to 30 is said to be moderate level of awareness while scores greater than 30 are said to belong to the category of "High level of awareness". The awareness level is then given a descriptive analysis and the result is presented in Table 2 .

Table 2: Teachers Level of awareness of Nigeria's educational policy on ICT

\begin{tabular}{|l|c|c|}
\hline & Frequency & Percent \\
\hline High level of awareness & 28 & 14.9 \\
\hline Moderate level of awareness & 94 & 50.0 \\
\hline Poor level of awareness & 57 & 30.3 \\
\hline Completely Ignorant & 9 & 4.8 \\
\hline Total & 188 & 100.0 \\
\hline
\end{tabular}


Table 2 shows the Teachers' level of awareness of Nigeria's educational policy on ICT. It can be seen from the table that most of the respondents are just moderately aware of the policy. In fact a considerable proportion of the respondents $(35.1 \%)$ of the respondents are either completely ignorant of the policy or possess poor levels of awareness of the policy. Only $14.9 \%$ of the respondents were found to possess a high level of awareness of the country's educational policy on ICT.

Research Question 2: Does teachers' attendance at previous ICT workshops/ trainings have any difference on their awareness of the policy?

To answer this research question, the respondents' scores on awareness was subjected to a test of difference on the basis of whether or not they have previously attended such training/workshops in the past few years using a t-test statistic. The result is presented in Table 3

Table 3. Test of difference in teachers' awareness of the educational policy on ICT on the bases o previous attendance at such training/workshops

\begin{tabular}{|l|r|r|r|r|r|r|}
\hline $\begin{array}{c}\text { Attendance at pre- } \\
\text { vious workshop }\end{array}$ & \multicolumn{1}{|c|}{$\mathbf{N}$} & Mean & Std. Deviation & df & t & Sig. \\
\cline { 1 - 4 } Yes & 60 & 23.3833 & 6.72736 & \multirow{2}{*}{178} & 0.388 & 0.699 \\
\hline No & 120 & 22.9417 & 7.42389 & & & \\
\hline
\end{tabular}

Table 3 shows the result of test of difference in teachers' awareness of the educational policy on ICT on the bases of previous attendance at such training/workshops. From the table, it can be seen that the t-value obtained in the test is 0.388 at $p=0.699$. Since the $p$-value surpasses the 0.05 threshold, it can be concluded that there is no significant difference in the level of awareness of the respondents on the basis of whether they have attended such workshops/training in the past. This can be interpreted to mean that the previous training which some of this respondents attended had no significant influence on their awareness of the country's educational policy on ICT.

Research Question 3: What is the teachers' response to the ICT use parameters considered in this study?

To answer this research question, the respondents' responses to items 15 to 24 in the section A of the questionnaire were given a descriptive analysis and the result is presented in Table 4.

Table 4. Teachers' response to the ICT use parameters in their schools

\begin{tabular}{|l|l|c|c|}
\hline & & Frequency & Percent \\
\hline \multirow{4}{*}{$\begin{array}{l}\text { Will you like to use computer in } \\
\text { your classroom teaching? }\end{array}$} & No & 6 & 3.2 \\
\cline { 2 - 4 } & Yes & 181 & 96.3 \\
\cline { 2 - 4 } & No response & 1 & .5 \\
\cline { 2 - 4 } & Total & 188 & 100.0 \\
\hline \multirow{2}{*}{$\begin{array}{l}\text { Can you use your own personal } \\
\text { computer in your classroom te- } \\
\text { aching }\end{array}$} & No & 48 & 25.5 \\
\cline { 2 - 4 } & Yes & 131 & 69.7 \\
\cline { 2 - 4 } & No response & 9 & 4.8 \\
\cline { 2 - 4 } & Total & 188 & 100.0 \\
\hline \multirow{2}{*}{$\begin{array}{l}\text { Do you have the ICT curriculum } \\
\text { in your school? }\end{array}$} & No & 11 & 55.9 \\
\cline { 2 - 4 } & cant say & 105 & 5.9 \\
\hline
\end{tabular}




\begin{tabular}{|c|c|c|c|}
\hline & Yes & 69 & 36.7 \\
\hline & No response & 3 & 1.6 \\
\hline & Total & 188 & 100.0 \\
\hline \multirow{4}{*}{$\begin{array}{l}\text { Do you have computers for stu- } \\
\text { dents' use in your school? }\end{array}$} & No & 150 & 79.8 \\
\hline & Yes & 35 & 18.6 \\
\hline & No response & 3 & 1.6 \\
\hline & Total & 188 & 100.0 \\
\hline \multirow{9}{*}{$\begin{array}{l}\text { If yes how many students are } \\
\text { normally allocated to use one } \\
\text { computer? }\end{array}$} & 1 & 1 & 0.5 \\
\hline & 10 & 9 & 4.8 \\
\hline & 15 & 2 & 1.1 \\
\hline & 20 & 5 & 2.7 \\
\hline & 30 & 6 & 3.2 \\
\hline & 4 & 1 & 0.5 \\
\hline & 5 & 4 & 2.1 \\
\hline & All & 1 & 0.5 \\
\hline & Total & 29 & 15.4 \\
\hline \multirow{5}{*}{$\begin{array}{l}\text { Are computers used for teaching } \\
\text { other subjects in your school? }\end{array}$} & No & 166 & 88.3 \\
\hline & cant say & 4 & 2.1 \\
\hline & Yes & 10 & 5.3 \\
\hline & No response & 8 & 4.3 \\
\hline & Total & 188 & 100.0 \\
\hline \multirow{5}{*}{$\begin{array}{l}\text { How frequently are students given } \\
\text { ICT-based assignments? }\end{array}$} & Never & 106 & 56.4 \\
\hline & Sometimes & 47 & 25.0 \\
\hline & Always & 15 & 8.0 \\
\hline & No response & 20 & 10.6 \\
\hline & Total & 188 & 100.0 \\
\hline \multirow{4}{*}{$\begin{array}{l}\text { Are computer skills taught in your } \\
\text { school }\end{array}$} & No & 88 & 46.8 \\
\hline & Yes & 94 & 50.0 \\
\hline & No response & 6 & 3.2 \\
\hline & Total & 188 & 100.0 \\
\hline \multirow{5}{*}{$\begin{array}{l}\text { How will you rate your students' } \\
\text { attitude to ICT }\end{array}$} & Repulsive & 24 & 12.8 \\
\hline & Indifferent & 38 & 20.2 \\
\hline & Enthusiastic & 75 & 39.9 \\
\hline & No response & 51 & 27.1 \\
\hline & Total & 188 & 100.0 \\
\hline \multirow{5}{*}{ Do you have an email address? } & No & 132 & 70.2 \\
\hline & Can’t say & 4 & 2.1 \\
\hline & Yes & 45 & 23.9 \\
\hline & No response & 7 & 3.7 \\
\hline & Total & 188 & 100.0 \\
\hline
\end{tabular}


Table 4 shows the teachers' response to some ICT use parameters considered in this study. From the table it can be seen that generally, virtually of the teachers sampled $(96.3 \%)$ like to use ICT in their daily classroom teachings and mostly $(69.3 \%)$ indicated that they could use their own (personal) computer system for this purpose. However, only $36.7 \%$ indicated that they have the National Computer Education Curriculum (NCEC) in their schools and only $18.6 \%$ have computers for students' use. Out of these, only $0.5 \%$ of the respondents reported that their schools have one computer for 1,4 or 5 student(s) while $2.7 \%$ indicated that 10 students make use of one computer in their school and 3.2\% indicated that 20 students make use of one computer. In fact, another $0.5 \%$ indicated that in their school, there is only one computer for all the students. Also $88.3 \%$ of the respondents claimed that computers are not used for teaching other subjects apart from computer literacy. Most of the respondents (56.4\%) reported that they never give students ICT-based or related assignment but despite that, a good percentage $(39.9 \%)$ of their students commonly demonstrate enthusiastically positive attitude towards the use of ICTs for learning.

Research Hypothesis 1: There is no significant influence of the respondents' perceived level of ICT skills on their awareness of the country's educational policy on ICT.

To test this hypothesis, the respondents' scores on awareness was subjected to a test of difference on the basis of their perceived level of ICT skills using ANOVA. The result is presented in Table 5

Table 5. Test of influence of the respondents' perceived level of ICT skills on their awareness of the country's educational policy on ICT

\begin{tabular}{|l|r|r|r|r|r|}
\hline & $\begin{array}{c}\text { Sum of } \\
\text { Squares }\end{array}$ & $\begin{array}{c}\text { Degree of } \\
\text { Fredom }\end{array}$ & Mean Square & \multicolumn{1}{c|}{ F } & \multicolumn{1}{c|}{ Sig. } \\
\hline Between Groups & 390.314 & 2 & 195.157 & 3.845 & .023 \\
\hline Within Groups & 9084.703 & 179 & 50.753 & & \\
\hline Total & 9475.016 & 181 & & & \\
\hline
\end{tabular}

Table 5 shows the result of the test of influence of the respondents' perceived level of ICT skills on their awareness of the country's educational policy on ICT. From the table it can be seen that the F-value obtained is 3.845 at $p=0.023$. Since the $p$-value fails to attain the 0.05 level of significance, the hypothesis stands disconfirmed and it can be concluded that there is a significant influence of the respondents' perceived level of ICT skills on their awareness of the country's educational policy on ICT. The researchers explored the source of the difference in the respondents' awareness level on the basis of their perceived level of ICT skills. Consequently, a multiple comparison test was conducted via Tukey HSD. The result is presented in Table 6.

Table 6. Multiple Comparison test via Tukey HSD

\begin{tabular}{|c|c|c|c|c|c|c|}
\hline \multirow[b]{2}{*}{ (I) a9 } & \multirow[b]{2}{*}{ (J) a9 } & \multirow[b]{2}{*}{$\begin{array}{c}\text { Mean Diffe- } \\
\text { rence (I-J) }\end{array}$} & \multirow[b]{2}{*}{ Std. Error } & \multirow[b]{2}{*}{ Sig. } & \multicolumn{2}{|c|}{$95 \%$ Confidence Interval } \\
\hline & & & & & $\begin{array}{l}\text { Lower } \\
\text { Bound }\end{array}$ & Upper bound \\
\hline \multirow[t]{2}{*}{ Poor } & Fair & -1.00431 & 2.68684 & .926 & -7.3543 & 5.3457 \\
\hline & Very good & -3.90086 & 2.60415 & .024 & -10.0554 & 2.2537 \\
\hline \multirow[t]{2}{*}{ Fair } & Poor & 1.00431 & 2.68684 & .926 & -5.3457 & 7.3543 \\
\hline & Very good & $-2.89655\left(^{*}\right)$ & 1.14567 & .033 & -5.6042 & -.1889 \\
\hline
\end{tabular}




\begin{tabular}{|l|l|r|r|r|r|r|}
\hline Very good & Poor & 3.90086 & 2.60415 & .024 & -2.2537 & 10.0554 \\
\cline { 2 - 7 } & Fair & $2.89655(*)$ & 1.14567 & .033 & .1889 & 5.6042 \\
\hline
\end{tabular}

* The mean difference is significant at the .05 level.

Table 6 shows the result of a multiple comparison test to locate which of the groups significantly differ from each other in their level of awareness and on the basis of their perceived level of ICT skills. It can be seen from the table that the mean difference between those who rated themselves as "very good" and "fair" is high and significant in favour of the "very good" group (Mean difference $=2.89, \mathrm{p}=0.033$ ). However, difference exists between the "Fair" group and the "poor" group but the difference is not significant.

Hypothesis 2: Teachers awareness of the country's educational policy on ICT will not significantly influence ICT use in Oyo state schools

To test this hypothesis, different parameters of ICT use in Oyo state were subjected to a test of difference via ANOVA and the result is presented in Table 7.

Table 7. Difference in ICT use parameters on the basis of teachers' level of awareness of educational policy on ICT

\begin{tabular}{|c|c|c|c|c|c|c|c|}
\hline & & & $\begin{array}{l}\text { Sum of } \\
\text { Squares }\end{array}$ & Df & $\begin{array}{l}\text { Mean } \\
\text { Square }\end{array}$ & $\mathrm{F}$ & Sig. \\
\hline \multirow[t]{3}{*}{ a15 } & \multirow{3}{*}{$\begin{array}{l}\text { Will you like to use } \\
\text { computer in your } \\
\text { classroom teaching? }\end{array}$} & Between Groups & .144 & 3 & .048 & \multirow{3}{*}{1.546} & \multirow[t]{3}{*}{.204} \\
\hline & & Within Groups & 5.664 & 183 & .031 & & \\
\hline & & Total & 5.807 & 186 & & & \\
\hline \multirow[t]{3}{*}{ a16 } & \multirow{3}{*}{$\begin{array}{l}\text { Can you use your } \\
\text { own personal compu- } \\
\text { ter in your classroom } \\
\text { teaching }\end{array}$} & Between Groups & 2.577 & 3 & .859 & \multirow{3}{*}{4.618} & \multirow{3}{*}{.004} \\
\hline & & Within Groups & 32.551 & 175 & .186 & & \\
\hline & & Total & 35.128 & 178 & & & \\
\hline \multirow[t]{3}{*}{ a17 } & \multirow{3}{*}{$\begin{array}{l}\text { Do you have ICT cur- } \\
\text { riculum in your scho- } \\
\text { ol }\end{array}$} & Between Groups & 2.255 & 3 & .752 & \multirow{3}{*}{.826} & \multirow{3}{*}{.481} \\
\hline & & Within Groups & 164.739 & 181 & .910 & & \\
\hline & & Total & 166.995 & 184 & & & \\
\hline \multirow[t]{3}{*}{ a18 } & \multirow{3}{*}{$\begin{array}{l}\text { Do you have compu- } \\
\text { ters in your school for } \\
\text { students' use? }\end{array}$} & Between Groups & 1.141 & 3 & .380 & \multirow{3}{*}{.612} & \multirow{3}{*}{.608} \\
\hline & & Within Groups & 112.373 & 181 & .621 & & \\
\hline & & Total & 113.514 & 184 & & & \\
\hline \multirow[t]{3}{*}{ a20 } & \multirow{3}{*}{$\begin{array}{l}\text { Are computers used } \\
\text { for teaching other } \\
\text { subjects in your scho- } \\
\text { ol }\end{array}$} & Between Groups & .248 & 3 & .083 & \multirow{3}{*}{.358} & \multirow{3}{*}{.783} \\
\hline & & Within Groups & 40.552 & 176 & .230 & & \\
\hline & & Total & 40.800 & 179 & & & \\
\hline \multirow[t]{3}{*}{ a21 } & \multirow{3}{*}{$\begin{array}{l}\text { How frequently are } \\
\text { students given ICT- } \\
\text { based assignments? }\end{array}$} & Between Groups & 3.772 & 3 & 1.257 & \multirow{3}{*}{3.035} & \multirow{3}{*}{.031} \\
\hline & & Within Groups & 67.937 & 164 & .414 & & \\
\hline & & Total & 71.708 & 167 & & & \\
\hline \multirow[t]{3}{*}{ a22 } & \multirow{3}{*}{$\begin{array}{l}\text { Are computer skills } \\
\text { taught in your school }\end{array}$} & Between Groups & 7.963 & 3 & 2.654 & \multirow{3}{*}{2.718} & \multirow[t]{3}{*}{.046} \\
\hline & & Within Groups & 173.839 & 178 & .977 & & \\
\hline & & Total & 181.802 & 181 & & & \\
\hline \multirow[t]{3}{*}{ a23 } & \multirow{3}{*}{$\begin{array}{l}\text { How will you rate } \\
\text { your students' attitu- } \\
\text { de to ICT }\end{array}$} & Between Groups & 3.742 & 3 & 1.247 & \multirow{3}{*}{2.175} & \multirow{3}{*}{.094} \\
\hline & & Within Groups & 76.273 & 133 & .573 & & \\
\hline & & Total & 80.015 & 136 & & & \\
\hline a24 & Do you have an email & Between Groups & 4.409 & 3 & 1.470 & 1.989 & .117 \\
\hline
\end{tabular}




\begin{tabular}{|l|l|l|r|r|r|r|r|}
\hline \multirow{2}{*}{ address? } & Within Groups & 130.773 & 177 & .739 & & \\
\cline { 3 - 5 } & & Total & 135.182 & 180 & & \\
\hline
\end{tabular}

Table 7 shows the result of test of influence of teachers' awareness of the country's educational policy on ICT use in Oyo state schools. From the table it can be seen that it has significant influence on only three of the ICT use parameters considered in this study. Teachers' awareness was found to influence the use of their personal computers in their classroom teachings, how frequently the students are given ICT based assignments, and ability of the teachers to teach computer skills.

\section{Discussion}

In terms of the implementation of educational reforms, teachers have been described as indispensable stakeholders that need to be consulted and involved in the formulation and implementation of any reform policy (Yusuf, Ajidagba, Yusuf, Olumorin, Ahmed, Daramola, and Oniyangi, n.d.). In fact, research has established the fact that it is the actual level of teachers' awareness about an ICT policy that determines its integration for use in education (Tondeur, Van Keer, van Braak and Valcke, 2008) and Sang, Valcke, van Braak, Tondeur \& Zhu (2011) found evidence that teachers' perception of an ICT school policy is a mediating variable in classroom use of ICT. Consequently, research question 1 was posed to determine the level of teachers' awareness of Nigeria's educational policy on ICT. The results shows that only a small percentage of the respondents were found to possess a high level of awareness of the country's educational policy on ICT, in fact, a considerable proportion of the respondents $(35.1 \%)$ of the respondents were found to be either completely ignorant of the policy or possess poor levels of awareness of the policy. This is consistent with what Ololube, Ubogu and Ossai (2006) found among lecturers that most of them do not know about the IT policy in Nigeria and hence cannot focus any of their teaching towards the goal of the policy as the teaching curriculum does not instruct so. Testing the first hypothesis however showed that respondents' awareness of the country's educational policy is influenced by the respondents' perceived of ICT skills, with those who perceived themselves as very good being more aware of the policy.

The Nigerian government in its bid to ensure a diffusion of the ICT innovation into the nooks and crevices of its educational system therefore organizes workshops and training for teachers across its education system either as a sole sponsorship, in partner with donor agencies, international development concerns, NGO and so on. It is expected that these workshops, apart from developing the requisite computer skills in the teachers, will also acquaint them with the necessary awareness of the government policy concerning ICT use in schools. Consequently, the second research question was posed to find out if teachers' attendance at previous ICT workshops/ trainings would have any influence on their awareness of the country's educational policy on ICT. The results indicated that the previous training which some of these respondents attended had no significant influence on their awareness of the country's educational policy on ICT.

Research question 3 was targeted at finding out how ICT is being applied in the classrooms of the schools from which the participants in this study were invited. The result of their responses indicated that ICT is not available in most of the schools in agreement with the findings of Adomi and Kpagban (2010) that computer is not part of classroom technology in more than 90 percent of Nigerian public schools. Where it exists, its use can be described as gross misuse where up to 20 students are allotted to one computer system or just one computer is available for all the students in the school. Consequently, such computers cannot be used for teaching other subjects apart from computer literacy as indicated by the respondents. Also teachers were not able to give students ICT-based or related assignment. However, a good per- 
centage $(39.9 \%)$ of their students commonly demonstrate enthusiastically positive attitude towards the use of ICTs for learning. To determine if the respondents' level of awareness of the county's educational policy affects the classroom use of ICT for teaching and learning, the hypothesis 2 , the results confirmed that it has significant influence on three of the ICT use parameters considered in this study. Teachers' awareness of the policy was found to influence the use of their personal computers in their classroom teachings, how frequently the students are given ICT based assignments, and ability of the teachers to teach computer skills. It did however not affect teachers rating of the students' attitude to the use of ICT in the classroom.

\section{Conclusion and Recommendation}

Given the acclaimed importance of ICTs to teaching and learning, the attendant effort of the Nigerian government to draw up a National Education Policy on ICT and the expressed influence of awareness of such policy on its implementation, there is a need to improve Nigerian teachers' awareness of any education reform policy and in particular, as it affects ICT in education. Future training, workshops or seminars designed for teachers across the levels of the Nigerian educational system should include the awareness, knowledge and understanding of this educational policy. It is expected that if the teachers are fully aware, they will be able to guide their learners to take full advantage of the provisions made by government, public spirited private individuals and Non-governmental organizations.

\section{References}

Achimugu, P., Oluwagbemi O. and Oluwaranti A. (2010) An Evaluation of the Impact of ICT Diffusion in Nigeria's Higher Educational Institutions Journal of Information Technology Impact $10(1), 25-34$.

Adebowale, O.F, Adediwura, A.A., and Bada, T. A., (2009). Correlates of computer attitude among secondary school students in Lagos state, Nigeria. International Journal of Computing and ICT Research, 3(2), 20 - 30.

Adebowale, O.F., Adewale, I. and Oyeniran, F.M. (2010). Computer interest, approval and confidence of secondary school students in three selected local governments of Lagos State (Nigeria): Implications for global computerization. International Journal of Education and Development using ICT (IJEDICT), 6(1), 40-52.

Adeosun, O. (2010). Quality basic education development in Nigeria: Imperative for use of ICT. Journal of International Cooperation in Education, 13(2), 193-211

Adomi, E. E. and Kpagban, E. (2010). Application of ICTs in Nigerian secondary schools. Library Philosophy and Practice 2010. Retrieved from http://digitalcommons.unl.edu/cgi/ viewcontent. cgi?article $=1353 \&$ context $=$ libphilprac

Agbatogun, A. O. (2010) Self-concept, computer anxiety, gender and attitude towards interactive computer technologies: A predictive study among Nigerian teachers. International Journal of Education and Development using Information and Communication Technology (IJEDICT), $6(2)$.

Agyeman (2007) ICT for Education in Nigeria. Survey of ICT and Education in Africa: Nigeria Country Report. Retrieved from www.infodev.org/en/Document.422.pdf

Ajayi, G. O. (2003). NITDA and ICT in Nigeria. 2003 Round Table on Developing Countries Access to Scientific Knowledge, The Abdus Salam ICTP, Trieste, Italy. Retrieved from

Albirini, A. (2004). "Teachers' attitude toward information and communication technologies: the case of Syrian EFL teachers". Computers \& Education, 47(4), 373-398.

Baylor, A. \& Ritche, D. (2002). "What factor facilitate teacher skill, teacher morale, and perceived student learning in technology-using classrooms?" Computers \& Education, 39(1), 395-414. 
Deniz, L. (2007). "Prospective class teachers' computer experience and computer attitude". International Journal of Social Sciences, 2(2), 116-122.

Federal Republic of Nigeria. (1998). National policy on education (3rd ed.). Lagos: Federal Government Press.

Federal Republic of Nigeria (FRN) (2004) National Policy on Education (Rev. ed) Lagos: NERDC Press

NITDA (n.d.) Nigerian National Policy for Information Technology (IT): 'USE IT’. Retrieved from http://www.uneca.org/aisi/nici/documents/it\%20policy\%20for\%20nigeria.pdf

Okafor, N. and Umoinyang, I. E. (2008). Towards enhancing Information and Communication Technology (ICT) compliance of the primary school teachers for effective teaching. Michigan State Teaching Association (MSTA) Journal, Fall 2008, 35 - 39

Okebukola, P. (1997). Old, new, and current technology in education. UNESCO Africa, 14(15), 718.

Ololube, N. P., Ubogu, A. E. \& Ossai, A. G. (2006). ICT and Distance Education in Nigeria: A Review of Literature and Accounts. In Proceedings of 2nd International Open and Distance learning (IODL) Symposium, September 13-15, 2006, Eskisehir, Turkey. pp. 643-655

Owhotu, V.B. (2006). Building the ICT capacity of language teachers: empirical insights and lessons for sub-Saharan Africa. FORMATEX: Current Developments in Technology-Assisted Education. 311-317.

Sang, G., Valcke, M. van Braak, J., Tondeur, J. and Zhu, C. (2011). Predicting ICT integration into classroom teaching in Chinese primary schools: exploring the complex interplay of teacherrelated variables. Journal of Computer Assistent Learning. Retrieved from http://ugent.academia.edu/JoTondeur/Papers/358277/Predicting_ICT_integration_into_classr oom_teaching_in_Chinese_primary_schools_exploring_the_complex_interplay_of_teacherrelated_variables

Tondeur J., Van Keer H., van Braak J. \& Valcke M. (2008) ICT integration in the classroom: challenging the potential of a school policy. Computers \& Education, 51, 212-223.

Wikipedia (2011). One laptop per child. Retrieved December 12, 2011 from http://en.wikipedia.org/wiki/One_Laptop_per_Child

Yusuf, M. O., Ajidagba, U. A., Yusuf, H. T., Olumorin, C. O. Ahmed, M. A., Daramola, F. O. and Oniyangi, S. O. (n.d.). The extent of basic school teachers awareness and involvement in the national basic education reform in Ilorin metropolis. Retrieved December 18, 2011 from http://www.musero.org.ng/publications/THE-EXTENT-OF-BASIC-SCHOOL-TEACHERSAWARENESS-AND-INVOLVEMENT-IN-THE-NATIONAL-BASIC-EDUCATIONREFORM-IN-ILORIN-METROPOLIS.pdf

Yusuf, M. O. (2007) "Trends And Barriers On The Integration Of Information And Communication Technology In The Nigerian School System. Retrieved January 12, 2012 from www.unilorin.edu.ng/publications/.../Trend\%20and\%20Barriers.doc

Received 10 March 2012; accepted 15 April 2012

\section{$\begin{array}{ll}\square & \square \\ \text { Olusegun Fatai Adebowale }\end{array}$}

Dr, Assistant Lecturer, Department of Educational Foundations and Counselling, Obafemi Awolowo University, Ile-Ife, Nigeria..

E-mail: oluadefat@yahoo.com, oluadefat@oauife.edu.ng

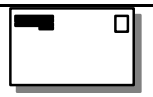

\section{Dare Naomi Olufunke}

Senior Tutor, Federal Government Girls` College, Ipetumodu, Osun State, Nigeria.

E-mail: naomi_dare@yahoo.com 